\title{
Shifting Urban Margins: Accessing Unequal Spaces of Ageing and Care in Zanzibar and
} Muscat

Sandra Staudacher, University of Basel, sandra.staudacher@unibas.ch

1. Faculty of Humanities and Social Sciences, Department of Social Sciences, Institute of Social Anthropology, Münsterplatz 19, 4051 Basel

2. Faculty of Medicine, Department of Public Health, Institute of Nursing Science, Bernoullistrasse 28, 4001 Basel

\begin{abstract}
Older people constitute a growing proportion of the urban population and are encountered in all kinds of spaces and neighbourhoods across cities. This article argues that urban seniority and elderly care are a fruitful, new lens to study how inhabitants on the social margins create urban space and social cohesion. This article draws on ethnographic research in the cities of Zanzibar, Tanzania, and Muscat, the capital of Oman. Many older inhabitants of cities experience frailty, serious health problems, or even disabilities and are no longer able to work or make a living, which pushes them towards the social margins. The ethnographic examples and reflections in this article illustrate, first, how cities can be investigated from the perspective of social and spatial marginality. Second, they show how urban dwellers' social positions can shift between the margins and centres of an urban society depending on their health and access to unequal spaces of ageing and care. And third, the paper analyses how some elders respond to marginality by taking up transnational and cosmopolitan agency.
\end{abstract}


This is an accepted manuscript of an article published by Taylor \& Francis in Anthropological Forum available at https://www.tandfonline.com/doi/full/10.1080/00664677.2019.1586644

\section{Towards a Broader Understanding of Cities: Lived Experiences of Ageing and Caring in} Urban Spaces1

My health condition is that I am old, and I am not strong anymore, and my legs are not healthy. My child cooks for me, I just receive the food. I can bathe myself. But I can't do the laundry ... I can talk and sleep. But I can't grate coconut, nor collect firewood, nor fetch water because of my chest. Asthma is always bothering me. Until I get an injection, I am unable to sleep ... I am not going to darasa [Islamic teaching class] these days. I cannot sit for a long time anymore and I can't walk. I would trouble people every day to go there, which is not good ... I can hear well but with my eyes I see darkness. 2

Even though Bi3 Sharifa stays with wealthy relatives, she lives on the urban margins. Her health condition in combination with her place of residence prevent her from participating in a lot of social activities in her family and the city. She does not have the energy (nguvu) or capacity (uwezo) to participate in urban life: that is, she hardly ever leaves the house. Bi Sharifa lives in Mpendae, a rather better-off area of Zanzibar, together with her niece's daughter and her family. The house is at the very outskirts of the city; living there constitutes an obstacle to her ability to move around freely. She would need to walk around 20 minutes to reach public transportation to go to the city centre for shopping or to the main hospital for a consultation. The mini bus (daladala) she would need to take is usually crowded, and for a frail, elderly woman like her, it is almost impossible to get into the bus since the clearance of the door is very high and the buses are always in a rush. Sometimes they do not even come to a complete stop to let people get in. During the rainy season, many of the streets turn into mud, and one needs a car with four-wheel drive if one can drive on them at all. Such street conditions, which are very common in all areas of the city, pose a severe obstacle for older people who are not strong walkers anymore. For them, slipping on the street can lead to a lifethreatening fracture.

The spatial dimensions of Mpendae are typical of better-off areas, which are built generously in terms of the space of the compounds and the space between different properties and which are mostly at the geographical margins of the city in areas where there was enough free space to build accordingly. It is not possible for Bi Sharifa to sit outside her home and chat with neighbours or people passing by because there is not a lot of foot traffic and her house is surrounded by a high wall, which is common in Mpendae. This means that she would have to 
be mobile to see people, but because she can hardly move, she is socially isolated. In my research, which I conducted between 2012 and 2015 in Zanzibar City, the research team encountered many research participants, both older people in general and especially older men and women with health issues, who hardly ever leave the compounds of their homes. If they become bedridden, they are likely to stay day and night in the same room with only very short visits, if any, from friends, family, and others. This means that older people in such situations tend to encounter other members of society on rare occasions. This physical and social absence from urban life pushes older people more and more towards what I call the social margins. Towards the end of their lives in the city, they become almost invisible: they lack information about what is happening on the streets, such as the latest gossip, developments, and opinions, and they cannot contribute to current debates. In other parts of the city - be it in Stonetown, the old part of the city, or in poorer areas where small properties of two or three rooms are closely lined up without any fence for privacy-spontaneous encounters are much easier. There, it is very common for older people to sit outside, and many of the houses even have an attached cement bench called a baraza (Loimeier 2007).

The case of Bi Sharifa illustrates how some inhabitants of the city who might be perceived as living on the urban margins can easily be forgotten by both urban planners and academics. Once older people become ill, frail, or disabled, they might be pushed to the urban margins, but as we will see later in Bi Sharifa's story, some elders can respond to marginality by participating in a transnational care space. They thereby shift between the urban margins and spatial as well as social centres depending on their health and access to unequal spaces of ageing and care.

Urbanisation and population ageing are two major developments shaping the twenty-first century. In studies about cities, older people are nevertheless underrepresented. The widespread disregard of older people and care for elderly people in urban research and policy is surprising since they constitute a growing proportion of the urban population and can be encountered in all kinds of spaces (Lefebvre 1974 [1996]) and neighbourhoods across cities. Both research on cities and the governance of cities primarily concentrate on centres as points of reference, whether they are spatial, social, political, or economic. The exponential growth of people living in cities and the rising number of older city dwellers is also observable in Africa. In this article, I present the case of the East African city of Zanzibar in Tanzania. The urban agglomeration of Zanzibar Magharibi (Zanzibar Urban West) has 569,000 inhabitants 
This is an accepted manuscript of an article published by Taylor \& Francis in Anthropological Forum available at https://www.tandfonline.com/doi/full/10.1080/00664677.2019.1586644

(United Nations 2015, 346), and 3.6 per cent of them are over 60, which is the official Tanzanian definition of 'elderly' (United Republic of Tanzania 2013, 47).

Many of the older inhabitants of Zanzibar experience frailty, serious health problems, or even disabilities. They often cannot work or make a living, which pushes them towards the social margins of the city and makes them dependent on their social network. The state institutions of elderly care in Zanzibar are weak, and pension schemes and health insurance are not widespread. Older people, their relatives, and their neighbours thus largely organise living and care arrangements privately. The World Health Organization report on Global AgeFriendly Cities (World Health Organization 2007) analyses several aspects of urban living that can exclude older people from fully participating in a city. Examples of potential exclusion are outdoor spaces and buildings; transportation; housing; social participation; respect and social inclusion; civic participation and employment; communication and information; and community support and health services. To look at the city from the perspective of older people means understanding the city in a way that an often-marginalised group of society does (see Kaiser-Grolimund 2018). This approach hints at how typical characteristics of cities like infrastructure, mobility, and diversity shape what the city is. These aspects provide the setting in which urban life happens. Particularly crucial, though, are the kinds of sociality (Long and Moore 2012; Amit et al. 2015) people engage in within these contexts. Accordingly, in this article I analyse how the actions of older inhabitants of Zanzibar are embedded in a dynamic matrix of sociality (Long and Moore 2012, 4). I look at how they make their way as actors through the city jungle, make use of its inherent possibilities and connectivity, and work on it by using their agency to create spaces of care not only in the city but also across national and continental borders, even though older inhabitants might be on the urban margins.

The ethnographic examples and reflections in this article illustrate, first, how cities can be investigated from the perspective of social and spatial marginality. Second, they show how the social positions of urban dwellers can shift between the margins and centres of an urban society depending on their health and access to unequal spaces of ageing and care. Finally, third, the paper analyses how some elders respond to marginality by activating transnational and cosmopolitan agency. This article thus aims at enhancing the development of a new discourse by looking at the agency (Emirbayer and Mische 1998) of older urban dwellers in the production and contestation of the urban margins in a city in the Global South. On the 
This is an accepted manuscript of an article published by Taylor \& Francis in Anthropological Forum available at https://www.tandfonline.com/doi/full/10.1080/00664677.2019.1586644

basis of Emirbayer and Mische (1998), I see agency as a temporally-constructed engagement of actors in different structural environments. Through the interplay of habit, imagination, and judgment, 'temporal-relational' contexts of action both reproduce and transform structural environments by recalling past personal experiences and imagining possible future trajectories (Emirbayer and Mische 1998, 970). Ageing and care are not the same for all older residents of Zanzibar. Emirbayer and Mische (1998) suggest that, based on the actors' experiences, three temporal dimensions of agency can be analysed: namely, orientations towards the past, the future, and the present. If we look at how older people experience, live in, and work on the city, then we should take into account their structural context, local social practices and norms, and their imagination of the future. By doing so, we can see that social relations are crucial to receiving care and that certain older inhabitants of the city are not only able to mobilise their social network on the island; they are also able to respond to their marginality with transnational and cosmopolitan agency. In this article, I thus focus not only on people's connections and engagements with others but also on how certain people are able to obtain access to unfamiliar ideas and goods coming from abroad and to use their agency in the sense of Emirbayer and Mische (1998). This allows them not only to know about certain things but also to depart from their habits and make creative use of new, alternative, foreign, or reinvented possibilities. I especially focus on how certain older people and their social networks are able and ready to mix ideas and thus draw on a cosmopolitan worldview to move away from urban margins at least in specific situations.

Out of the fifty research participants in Zanzibar, thirty-seven had relatives abroad, but this did not mean that they could automatically expect care or support from them. Most of the older people in the city of Zanzibar find themselves in one of the following four spaces: first, a localised space of ageing and care; second, a cosmopolitan space of ageing and care; third, an occasionally transnational space of ageing and care; or, fourth, a transnational space of ageing and care. In these spaces, I understand the concept of space as dynamic ('doing space') (Herzig and Thieme 2007, 1079). Space is reproduced relationally in everyday practices and can be defined as the product of iterations between social practices and place. With regard to these four spaces of aging and care, which I will briefly summarising here and elaborate on in detail elsewhere (Staudacher 2018), this article focuses on aspects of cosmopolitan and transnational agency. 
This is an accepted manuscript of an article published by Taylor \& Francis in Anthropological Forum available at https://www.tandfonline.com/doi/full/10.1080/00664677.2019.1586644

If older urban residents are situated in what I call a localised space of ageing and care, their agency is limited to a narrow local field in their social and spatial surroundings. By this I mean that they do not have relatives abroad or are not in contact with them. In this specific urban space, access to what I call cosmopolitan living - the willingness and possibility to engage with cultural 'others' (Skrbis, Kendall, and Woodward 2004)—is hardly possible. Older people mostly do not have the means to maintain relationships with relatives who live elsewhere since many of these older people and their families live in poor places where, for example, access to means of communication and transportation are limited; and if their relatives visit the city, they are more likely to choose to stay with somebody who can offer better housing, food, and transport. In a localised space of ageing and care, older people are often not able to overcome major health crises, or they live with untreated chronic conditions.

A second space of ageing and care points to a cosmopolitan orientation of older people in the city of Zanzibar. I understand their cosmopolitanism as 'a discursive and performative practice' that reflects 'a sophisticated appreciation for international mixing and appropriation of cultural styles and symbols from multiple, geographically dispersed sites' (Fair 2004, 13). Cosmopolitanism even becomes a lifestyle and moral position (Kleinman 2012). Levitt and Glick Schiller $(2004,1008)$ argue that the literature on cosmopolitanism neglects exploring social relations and positioning, and focuses on the intersection of the individual and the global. I aim to bring the contexts, structures, and practices of cosmopolitanism together. Having said this, it is important to acknowledge that many of the people living in Zanzibar are very much connected to other parts of the world. Some have ancestors from the Comoros, India, or Oman, and they still cultivate relationships with (extended) family in these places. Quite a few of my older research participants, and especially the male ones, had spent time abroad studying or working (including as football players and actors). And there are also many families that trade with or import goods from Dubai, India, and China (Verne and Müller-Mahn 2013). Many older people in Zanzibar who inhabit such a cosmopolitan space of ageing and care orient their practices towards many different cultural spaces at once. They usually have a higher education and are financially capable of translating their ideas into practice. The case of Mzee Cheetah illustrates how older urban inhabitants in a cosmopolitan space of ageing and care might draw their agency from a range of experiences in diverse social and cultural spaces. Accordingly, he and his family decided, for example, to try out all kinds of treatments at the same time. 
Another space in which older Zanzibari can be situated is what I call an occasionally transnational space of ageing and care. It overlaps with the fourth space, the transnational space of ageing and care, but it is clearly less intensive in its transnational quality. Older people who lead an occasionally transnational life have acquaintances or relatives outside the country (mtu au jamaa nje ya nchi), but they are only sporadically in contact with them. They typically receive visitors from abroad for a short time, and they call each other on important holidays, such as Eid al Fitr. They usually can expect help from relatives abroad in case of an emergency like a health crisis.

The fourth space, the transnational space of ageing and care, concerns older people who have one or several relatives or acquaintances abroad and receive a lot of care from them in a broad sense. They communicate with relatives abroad at least on a weekly or monthly basis, often receive regular remittances, and visit each other. They may go for medical treatments abroad, exchange gifts, and receive medications and medical tools. Relatives abroad often support the older person through their networks in and outside of Zanzibar.

To attain its objectives, this study draws on ethnographic data from seventeen months of research conducted between 2012 and 2015 among older people and their social networks in the city of Zanzibar (Tanzania) and from two months in Muscat, the capital of the Sultanate of Oman. The research team in Basel and assistants in Zanzibar selected fifty seniors through transect walks in four diverse areas of Zanzibar. Through guided interviews with open-ended questions, informal talks, and observations, we gathered an enormous quantity of information on their health, ageing, and care arrangements in Zanzibar. Besides doing interviews with older people themselves, we used the 'go along' method (Kusenbach 2003): spending a lot of time joining them in whatever they were doing, like cooking, walking to nearby places, sitting around, and going to mosques or farms. We also interviewed the relatives whom seniors mentioned as their most important support. Additionally, I travelled with one of my research assistants from Zanzibar to Muscat to spend two months with relatives of the older research participants. The aim was to obtain insights into the transnational social spaces in which some older Zanzibari are integrated, spaces that they often access once they are confronted with 'critical health moments', which Obrist $(2016,96)$ describes as events of 'discomfort, unease, pain or inability to perform as usual'.4

\section{The City between the Centre and the Margins: Theoretical Reflections}


There are four major deficiencies in the current research that I want to address in this article.

First, there are few studies with an actor-centred approach to cities in general and even fewer with a focus on urban ageing and elderly care (Koechlin 2015; Gerold 2013; Kleinman and Van der Geest 2009; Kleinman 2012). In the dichotomous discourses on elderly care in the region, scholars either argue that the social structures supporting older people are falling apart, or they praise 'African solidarity', how people help each other out (Makoni and Stroeken 2002). This article wants to move beyond the divergent discourses on cities either as hubs of exclusion, informalisation, criminalisation, insecurity, and poverty (Koechlin 2015, 16) or as spaces of diversity and creativity where people connect and are its infrastructure (Simone 2004).

Second, the literature on cities has neglected the analysis of urban margins as major parts of cities. Instead it tends to view the margins as undeveloped parts of the city. I start from the presumption that urban inhabitants living on the margins of a city do not at all represent negligible minorities of the urban whole. Rather, in line with the editors of this special issue, I argue that those at the city's margins co-constitute the city; in other words, a city is also defined by its margins. By focusing on the margins in this article, I do not seek to reproduce processes of marginalisation that create those margins but rather to contest the assumption that the margins are marginal by moving the urban peripheries to the centre of academic interest.

A third deficiency in the research is that most studies on cities were conducted in Western metropolitan cities. There is an urgent need to include more cities of the Global South in the theorisation of cities and urban spaces (Robinson 2011, 2006). Since especially small (Bell and Jayne 2006) and mid-sized 'secondary' cities are underrepresented in the literature, the city of Zanzibar constitutes a perfect case for enriching our understanding of what cities are.

Finally, there is also a lack of research on how transnational processes are connected to ageing, health, and care and how even city dwellers on the urban margins relate to transnational social spaces. Rapid transformations of urban spaces in Africa are not only produced by new actors and social formations, as Koechlin $(2015,16)$ argues, but also especially through a strengthened connectedness of translocal and transnational relations 
This is an accepted manuscript of an article published by Taylor \& Francis in Anthropological Forum available at https://www.tandfonline.com/doi/full/10.1080/00664677.2019.1586644

between people who live a significant distance from one another but may or may not live in the same city or country.

Currently, as is outlined in the introduction of this special issue, we can observe two prevalent discourses on the urban in social anthropology: a right-to-the-city discourse and a creativityin-the-city discourse. 5 The first sheds light on the impeded access to urban citizenship and problematises inequalities and processes of inclusion and exclusion. Authors following this strand point to the unequal distribution of resources, limited access to urban infrastructure, reduced participation in the urban economy, and the lack of social and political recognition for people on the urban margins (Lefebvre 1974 [1996]; Harvey 2012; Caldeira 2000). They especially describe African cities as places of informality, criminality, insecurity, and poverty (Myers 2011; Koechlin 2015, 16). In this line of research, authors often implicitly understand the centre of a city as the point of reference for what a city is or should be. Most of the policyoriented publications of international organisations and NGOs can be assigned to this perspective, especially when they focus on what some have called the 'hard city' (Raban 1974), which refers to its material and physical aspects such as infrastructure and its mobility networks such as means of communication and transportation (Freudendal-Pedersen and Cuzzocrea 2015, 4).6

The second discourse, which is more oriented towards the meanings, imaginations, and myths that constitute the 'soft city' (Raban 1974), can be called the creativity-in-the-city discourse. It conceives of the city as an enabling place. Authors following this strand bring the diversity of a city's inhabitants to the forefront and emphasise how the initiative of urban dwellers creates new, creative, and innovative spaces and practices (Obrist 2013; Förster 2013; Nuttall and Mbembe 2004). Other authors have investigated how networks of people become a city's infrastructure (Simone 2004).

In this article, I aim at going beyond these two discourses by stressing the situational and fluid character of sociality in cities. With the concept of urban margins, I do not primarily refer to informal settlements or other specific neighbourhoods as places 7 at the geographical margins of cities but rather to the social, cultural, economic, and political margins, that is, to the social spaces 8 of cities (Keshodkar 2013, 7). Lancione $(2016,4)$ reminds us that

[i]n focusing a priori on a definition of what the margins and borders are, or in trying to contain their heterogeneity into strict theoretical boxes, a whole set of fundamental 
This is an accepted manuscript of an article published by Taylor \& Francis in Anthropological Forum available at https://www.tandfonline.com/doi/full/10.1080/00664677.2019.1586644

things - like the nuanced way power and affects work in the everyday life of people and their spaces - get dismissed or not adequately acknowledged.

The aim is thus not to stereotype urban margins and centres further according to categories of inclusion and exclusion but to look at how urban dwellers live and create social spaces.

When older people are confronted with health problems, they cannot—or are not supposed to-do the same things they did when they were healthy, like earn an income, take care of grandchildren, go to the market, or attend festivities. They can expect to receive certain kinds of care, depending on their health situation, gender, class, and family or other social relations. Based on his research in Indonesia, Van Eeuwijk (2002, 25; 2004, 124) suggests that older people face a 'triangle of uncertainty' with social, economic, and health dimensions, which constitutes the context of 'old-age vulnerability'. He argues that there is no guarantee that older people will receive care. I use the concept of care in a broad sense, not distinguishing cure from care (Mol 2008) and including its technical, practical and emotional elements as defined by Kleinman and Van der Geest $(2009,159)$. I thus understand all activities that make the daily life of older people more bearable (Mol 2008, 1) — such as washing, feeding, and visiting with someone as well as dressing wounds - as part of elderly care. It is important to understand that giving and receiving care 9 are social practices that constitute social spaces in and beyond the city.

In the case of Zanzibar, care spaces transgress not only the city but also national and continental borders by reaching to the Arab Peninsula, Europe, and the United States. Recent research in medical anthropology has shown a newly emerging interest in ageing and transnational care (Baldassar and Merla 2014; Dossa and Coe 2017), but this research is rarely connected to cities. I understand transnationalism 'as a social process whereby migrants operate in social fields that transgress geographic, political and cultural borders' (Glick Schiller, Basch, and Blanc-Szanton 1992, ix). Many ageing migrants operate in social fields that expand not only to their city or country of origin but also to other nations where relatives have settled (Lamb 2009).

There are studies on transnational urbanism10 that look at globalisation processes and transnational flows in cities, but they rarely touch on the transnational networks of ordinary city dwellers. Older people are completely absent in these discourses. The migration of people, ideas, and resources is not, however, a new phenomenon, and many migrants of 
This is an accepted manuscript of an article published by Taylor \& Francis in Anthropological Forum available at https://www.tandfonline.com/doi/full/10.1080/00664677.2019.1586644

different historical periods have lived in social fields spanning from the city and country of residence to the city and country of origin or even to other countries if the migrants were also engaged in trading. Most Zanzibari, and especially those residing within the city, identify as Swahili and are a well-known example of a mercantile civilisation (Middleton 2004). The Swahili have created social fields reaching from their urban communities on the East African coast to the Arab Peninsula and South Asia. Founded by Arab migrants, urban Swahili communities have developed a rich cosmopolitan (Fair 2004, 13; Larsen 2004, 123) culture drawing on Arab, African, and Asian traditions (Caplan and Topan 2004; Mazrui and Shariff 1994). Their social spaces have a transitory, shifting, and plural character, and they display varying degrees of engagement and exchange with Islam, (Western) modernity, and globalisation (Loimeier and Seesemann 2006, 1). The broad literature on Swahili transnationalism (Al Rasheed 2005; Mazrui 2007) has not yet answered how (older) city dwellers relate to these cosmopolitan and transnational processes and has not paid enough attention to the diversity in intensity and kinds of participation in transnational and cosmopolitan social spaces.

\section{The Struggle for Urban Ties}

What shifts elders in urban Zanzibar to the margins is the fact that the majority are suffering from a chronic disease, a disability, frailty, or at least from a temporary but frequent health problem. By their places of residence, older people are distributed across virtually the whole city. Although they are part of diverse social groups and classes, one common denominator increases the likelihood that they live or are being pushed towards the urban margins: their health situations.

In the following, I will illustrate situations of older people on the urban margins by presenting two cases. First, the case of Mzee (the respectful address for an older man in Swahili) Cheetah, who is in his early seventies, lives in an area bordering the city centre, and, because of a stroke, was suddenly transformed from a relatively healthy breadwinner for two families to a paralysed, debilitated old man. And second, in the next part, we will come back to Bi Sharifa, the frail widow around eighty-five years old whom I introduced at the beginning. She does not have biological children and lives in a newer and better-off area of the city. These two cases represent typical gendered experiences of ageing in the city of Zanzibar and depict how different health situations impact whether social spaces can be accessed or not. 
Mzee Cheetah's story illustrates how illness and disability can have an enormous effect on the financial, political, social, and cultural aspects of an older person's life. When I met Mzee Nassor Suleiman Nassor for the first time in June 2012, he was seventy years old and had two wives and six children. We met at his home in an older area of the city. He introduced himself as Mzee Cheetah; nobody knows his official name anymore, and everybody just calls him 'Cheetah' after the fastest land animal. The energetic man lived up to his name. Even though he was officially retired and was receiving a pension, he was still employed at a governmental institution, where my assistant Saleh and I met with him many times for talks and interviews. In the past, he had played traditional music taraab, and he proudly told us about all the places in the world he had visited thanks to his employment in the cultural sector. For a long time, he was the coach of female netball and football teams. Above all, Cheetah was famous across the island as an actor in popular movies that were shown on local television. I was impressed by the notecards he always kept in the pockets of his trousers where he carefully wrote down all the things he wanted to do in a day. He was constantly busy trying to provide his first wife, their children, and his second wife — with whom he did not have any children — with everything they needed in life. Besides his work, he regularly went to the nearby market to buy food. He stayed mobile by bringing his son to school every day. As an active member of a diabetes self-help group, he was consciously concerned about his health, and by building a new home outside the city, he was making financial plans for his retirement. Even though he considered himself strong, he told us about how diabetes had led to numbness in his legs and feet and the loss of his virility (nguvu ya kiume, literally translated: 'male power'), which worried him a lot. Half a year later, he felt much better and explained that he was not suffering from health problems anymore. He explained to us that it was necessary to be very active if he wanted to remain in a condition in which he would be able to do what he wanted to do:

I feel okay and strong because I can do what I want to do. But there are some in my age that are in a bad condition. But as for me, I am so well that I can run from here to $\mathrm{K}$ [around 10 minutes] and now I am working at A [governmental institution] under a contract. So, I think that I will be in the countryside gardening when my contract finishes. Therefore, I am trying to finish my house, to live in the shamba [countryside] because then I will not be working [under a contract anymore].

While I was away from Zanzibar, Saleh tried to call Mzee Cheetah many times without him answering the phone. Finally, he went to visit him and learned from Mzee Cheetah's first wife 
This is an accepted manuscript of an article published by Taylor \& Francis in Anthropological Forum available at https://www.tandfonline.com/doi/full/10.1080/00664677.2019.1586644

that he had a stroke with drastic consequences. He suddenly could not walk or talk anymore, and one side of his body was paralysed. He tried to talk to Saleh but had to give up because not a single word was understandable. When I was back in Zanzibar, we met Mzee Cheetah at his first wife's house. He was sitting in a chair in the living room. He had lost a lot of weight, but according to Saleh, he was in better condition than the last time he had met him. He could walk slowly, but he could not go more than a few houses away. He was not able to talk, but he could smile a little, and he seemed to understand everything we said. Mzee Cheetah was nodding and trying to talk, but I could only guess what he was trying to say. As we have seen, Mzee Cheetah was an extremely social person with countless friends and acquaintances, but after the stroke, many relationships faded. Several of his friends and neighbours told me that he was not the person he used to be, and one even made fun of him by imitating him.

This is of course an extreme example of how social relations and engagement in the city can change with health issues. But I met many frail older people who went through similar experiences over longer periods, often over many years. The social network of such a person could be very well-disposed towards them, but after a while, visits become less frequent, and the majority just pass by to ask them one or two questions and do not stay longer than a few minutes. One of the female research participants complained to me that people paid her fewer visits and just quickly called her on her mobile phone instead of spending time with her. As a researcher, I often sensed the desire, especially from older women, to talk and be heard, and of course I was always flattered if they pointed out to the people they were living with that now everything else could wait since they had a guest and did not want to be interrupted for several hours.

While older men who felt more or less healthy and still had strength (nguvu) were often consulted if any kind of problem arose among their relatives, a serious health condition also implied losing their status as a social, cultural, and religious authority both within the family and beyond. Some relatives of older men told me that they could not take their frail father or grandfather seriously anymore, and that these older men had become child-like. They did not earn a living anymore, and because they stayed at home away from the latest developments and news in the city, they often were not able to make well-informed decisions. In the city of Zanzibar, women largely practice their religion at home while most men regularly (up to more than five times a day) go to pray at a mosque. So, a health situation that prevents them from 
This is an accepted manuscript of an article published by Taylor \& Francis in Anthropological Forum available at https://www.tandfonline.com/doi/full/10.1080/00664677.2019.1586644

leaving the house alone or from performing prayers outside the house means that these men lose a major part of their daily routines and social contacts.

The case of Mzee Cheetah shows that there may be a large difference between somebody with a chronic condition like diabetes or experiencing a loss of energy, which might hinder them in certain situations from doing what they would like to do on their own (kujiweza), and somebody who suddenly suffers a life-changing health condition like a stroke and has to live with its severe consequences. Such impairments require urgent responses to health issues. The degree of health problems, impairments, or frailty thus fundamentally affects an elderly person's position in urban society.

\section{Experiencing, Living, and Working in the City to Receive Care}

If we look at how cities are experienced, lived in, and worked on by older people on the social margins, then we can see that social relationships are crucial to receiving care. On the island of Zanzibar, with its decade-long transnational relations, elderly city dwellers respond to their marginality with what I call transnational and cosmopolitan agency.

In Zanzibar, governmental support for elderly care is scarce, and only 4.9 per cent of the population over sixty has a pension from the Zanzibar Social Security Fund (Zanzibar 2012), which is a contributory pension scheme. The older people who do receive a pension are mostly former state employees. Public healthcare is free in Zanzibar, but it only includes basic examinations. Medications, X-rays, blood check-ups, and surgeries are not covered. Despite the paucity of the free public healthcare, it is uncommon to possess additional health insurance and, out of the fifty randomly sampled older research participants, only one woman had an insurance plan.

We can take Bi Sharifa and Mzee Cheetah as examples of the effects of financial situations on healthcare. While Bi Sharifa does not have a pension, she is in a relatively privileged position financially. Yet she still must actively engage with others to receive care. Mzee Cheetah receives a comparatively large pension, but it does not nearly cover his expenses, especially since he is impaired and needs medical treatment. Building a home for the time after retirement and being a caring father and husband have helped him receive care. For both research participants, their agency shapes how they experience, live in, and work on the city, 
This is an accepted manuscript of an article published by Taylor \& Francis in Anthropological Forum available at https://www.tandfonline.com/doi/full/10.1080/00664677.2019.1586644

but it is of course impossible to overcome their health issues completely. Instead, they can only influence their situations and positions in the city to a certain degree. Since Bi Sharifa is not mobile anymore, she needs help with almost everything:

If there is travel, we get in a car, [for] going to town, or outside the city [shamba], or to weddings, which are important to us. Sometimes we go out for a visit in the evenings, I, Mama, Baba [which means father, but she refers to the husband of Mama as Baba], and the children. But I do not do anything, they do everything, they just tell me to wait for my plate.

Besides the care she receives during the day, she sleeps in a room together with two young girls, the daughters of Mama, who assist her at night. Bi Sharifa was married three times. In the first marriage, she bore a child who died soon after birth. Because she could not have any more children on her own, she raised two of her nieces' children and took on the responsibilities of a mother when she helped one of her niece's daughters during the first months after she had a child. Her first and second husbands divorced her, and her third husband died twenty years ago. After his death, she lived for a year alone on Pemba, a smaller neighbouring island that is part of Zanzibar, where she had built her own house with the financial help of relatives in Oman. Then Bi Sharifa spent some time with members of her late husband's family. When she became weaker, Mama encouraged Bibi to stay with her in the city of Zanzibar together with her husband, children, and two household helpers who do not sleep in the house. Bi Sharifa mentioned Mama and the son of another niece, who lives in Oman, as the most important people helping her. About Mama, Bi Sharifa said: 'She does everything. She is my Mama. It is not one or two things that she does for me. She does everything, all the work is up to her: eating, dressing, traveling, sleeping.' Depending on the day, Bi Sharifa either praised Mama or complained that no one is interested in her advice anymore and that she cannot help the children with their schoolwork or Mama with the cooking because all the recipes have changed. Bi Sharifa often stays for several months with other relatives whom she helped when she was younger, and the last time I met her, she had moved in with her niece, who is just a few years younger than her. She told me that it was very peaceful to live with another older person since people in the same situation understand her concerns best.

The example of Bi Sharifa shows that the situations of older people can shift constantly. She needs help, but she can also influence, to a certain degree, whom she stays with, and she makes her 'children' compete over hosting her. In four different houses, people told me that 
This is an accepted manuscript of an article published by Taylor \& Francis in Anthropological Forum available at https://www.tandfonline.com/doi/full/10.1080/00664677.2019.1586644

they appreciate it when Bi Sharifa stays with them. I argue that Bi Sharifa moves around so much as a strategy to receive the best treatment she can. If she stayed longer in one place, she would receive less attention and care. Additionally, by addressing, for example, her niece's daughter as Mama, she invokes Mama's responsibility to take care of her like a child.

The financial capacity of a family is of course a major precondition for taking care of an older person (De Jong, Roth, Kinda, and Bhagyanath 2005). Nevertheless, I also observed that care encompasses much more than what money can buy. Most older people knew very well what was financially possible for the relatives they lived with, and they appreciated whatever they received. But even in poorer areas, care did not just happen but was negotiated and worked hard for through establishing reciprocal relations and invoking religious arguments of what one was supposed to do for a mother, a parent, or any elderly person.

Mzee Cheetah could count on part of his social network. After the stroke, his wife coordinated his medical treatment at the hospital and at home with an herbalist. She commented: 'I am now the father and the mother.' He went to the hospital together with his daughter who had been living in Oman. She did not return to work in Oman because of her father's condition. She was sleeping at her father's place even though she is married. Her husband stayed somewhere else. After the stroke, Mzee Cheetah was in the hospital for one week, and then he left even though the medical staff asked him to stay another week. Cheetah's wife complained that the medical staff did not explain the illness to them, and she also did not see any improvement after one week. The doctor told them that he should do exercises, move, and try to talk. When they talked to him, he grimaced and became angry, perhaps because he felt they were making fun of him. Cheetah made use of a wide range of treatments provided by biomedical doctors, an herbalist, and an Islamic spiritual healer, which his first wife also organised.

The example of Mzee Cheetah shows us how quickly care arrangements can change. From being a care provider, who was responsible for the family's income and for bringing his son to school every day, he became completely dependent on his wife and daughter. According to the first wife, the second wife had only come once to see her husband in all the months since his stroke, and she did not contribute financially to the medical treatment. The pension became more important to the financial livelihood of the family than it was before, even though it did not cover their expenses. They rented out the house that Mzee Cheetah built for 
This is an accepted manuscript of an article published by Taylor \& Francis in Anthropological Forum available at https://www.tandfonline.com/doi/full/10.1080/00664677.2019.1586644

retirement to supplement their income. Neighbours came around and brought small amounts of money, but they mostly visited only for a very short time since Mzee Cheetah was not able to talk anymore.

Older inhabitants of the city draw on their experiences of responsibilities, obligations, norms, and values to deal with specific situations, demand care, and imagine the future. Mzee Cheetah carefully planned his day-to-day life and his future retirement, but he could not foresee that he would suffer a stroke, which would prevent him from working in the big garden of the house he built outside the city. It was through imagining potential future situations that Mzee Cheetah created strategies to change his prospects. Before his stroke, Mzee Cheetah built on his past experiences and habits (Emirbayer and Mische 1998). He not only constructed an additional house; he also paid into a pension scheme and established a large family.

After the stroke, Mzee Cheetah had to reorient himself as much as he could. He could not become the healthy retired man working in the garden he had imagined. His experience gained a new dimension (Emirbayer and Mische 1998). But he could still partially rely on what he had imagined before: the pension and, especially, his family. Receiving care is, of course, not as simple as that. The care provided by others, mainly by family, is, as in the case of Mzee Cheetah, always situated within a complex net of responsibilities, obligations, norms, and values that are also linked to being part of a specific generation (Alber and Häberlein 2010; Van Eeuwijk 2006; Van der Geest 2002; De Klerk 2011). Old-age care is often specifically connected to respect and reciprocity (Van der Geest 2002).

\section{Expanding the City: Transnational Agency}

To illustrate how transnational ageing and care space is created, lived in, and accessed by an elderly woman on the social margins in Zanzibar, I would like to add an additional piece of Bi Sharifa's case: the perspective of her niece's son who lives in Muscat and regularly communicates with her.

Bi Sharifa brought up her niece's son Omar as if he were her own son. When I was with her, she did not talk about him often, but she gave us his phone number and some sweet and salty snacks for him when we told her that we were planning to go to Oman to meet the relatives of 
older people in Zanzibar. Omar, who is in his late forties, mostly lived with Bi Sharifa before he went to Oman. Omar moved to Oman with a scholarship to study Arabic twenty years ago. After he married in Muscat, he sent a visa to Bi Sharifa, who came to visit him for four months. Since then he has travelled to Zanzibar once every year. He calls Bi Sharifa every day even though it is not always easy because she has lost many mobile phones. If he does not reach her, he can call his siblings since she lives with them in Zanzibar. He said that he makes sure he provides her with everything. Doing less would make him feel imperfect considering all that she has done for him. Omar, who is an imam and takes care of the neighbouring mosque, told us that the Quran advises people to live with their parents and other older people and to provide them with whatever they want without complaining. Additionally, he mentioned that one should help a mother three times more than a father. Omar regularly sends money to Bi Sharifa. If she needs more financial means, for example for a health treatment, he arranges for his brother in Dar es Salaam to send her the amount. Omar tried to convince Bi Sharifa to live with him in Muscat, but she told him that she does not want to do so because she could not move around independently without driving a car in Oman.

This example shows how the relatives of older Zanzibari have been living for decades in Oman, but they still feel responsible and care for older family members in the city of Zanzibar. The older research participants in Zanzibar mostly understand obligations to transnational ageing and care as resulting from the education of their children and from their familial relationships, which create expectations and duties for both sides.11 Even though it might look at first glance like older urban residents were just receiving this care over a distance, these transnational spaces result from negotiations between older Zanzibari and their relatives abroad, and in certain situations they could, at least to some extent, move the older people away from social and spatial marginality in the city.

\section{Conclusion}

How urban dwellers' social positions shift between the social margin and social centre of an urban society is interdependent with their changing health situations. The example of urban elderly people shows us that they are at risk of being excluded from the urban centre, especially if they have a major health issue. More particularly, the cases illustrate the differences between suffering from a chronic condition and experiencing a life-changing 
This is an accepted manuscript of an article published by Taylor \& Francis in Anthropological Forum available at https://www.tandfonline.com/doi/full/10.1080/00664677.2019.1586644

health event. The degree of health problems, impairments, or frailty thus fundamentally affect an older person's position in urban society (Obrist 2016).

This article has further argued that in accessing unequal spaces of ageing and care, some older people can respond to social and spatial marginality with transnational and cosmopolitan agency while others cannot. Long-distance care can overcome some of the aspects of urban marginality that older people experience once they become seriously ill or frail. These dynamics show how fluid and porous social urban margins and centres are. Understanding a city and its urban margins requires integrating transnational and cosmopolitan experiences, relations, and possibilities into the analysis.

In cases of a health emergency older people's agency in the sense of Emirbayer and Mische (1998) becomes observable when care is arranged or performed. This means that agency can be observed in the present bargaining processes of negotiation for or activation of care arrangements (Kleinman and Geest 2009, 159). If an older person is confronted for example with a sudden health crisis in a city like Zanzibar, where state services for elderly people are scarce, family members largely fill in the gap. Familial relationships and generally gendered kinship ties are, accordingly, crucial to care giving. In such a situation, the agency of an older person is essential to obtaining care.

Depending on their habitual backgrounds, elderly inhabitants of the city draw on their experiences of responsibilities, obligations, norms, and values to cope with specific situations, demand care, and imagine the future. Old-age care is, for example, often specifically connected to respect and reciprocity (Geest 2002). My research resonates with Freeman's analysis $(2018,119)$, which showed how the experiences and expectations of receiving care of elderly people were situated "within a complex web of support networks, based on a principle, if not practice, of reciprocity". In transnational care relations, reciprocity played an important role in providing (often expensive) support in health crisis. The way older people experience specific health situations, happens remarkably often in a gendered way. While for many men, situations of health crisis rather meant moments of rupture and uncertainty, in which they had to reorient themselves and change the imagination of their future, typically, women could more rely on their past and future orientations in order to deal with the present situation. Both though, older men and women, became especially engaged in spaces of aging and care beyond the city in situations of health crisis. In such situations, they activated on one 
This is an accepted manuscript of an article published by Taylor \& Francis in Anthropological Forum available at https://www.tandfonline.com/doi/full/10.1080/00664677.2019.1586644

side their transnational networks outside Zanzibar and on the other side they used their cosmopolitan experience to deal with the given health problems and to receive care.

The example of older people reminds us to think critically about how we understand cities with their social and spatial centres and margins. It is important to consider how the actors themselves constantly negotiate and create urban spaces, and they do so not only in the city but also across national and continental borders. The analysis of this study has shown that urban margins, like urban spaces, are in continuous flux. These urban spaces shape and are shaped by the city's dynamics and inhabitants. Who is at the centre and who is on the margins is the outcome of contestations, negotiations, and dissolutions enacted through social practices. This dynamic is especially visible in spaces of ageing and care.

\section{References}

Al Rasheed, M. 2005. Transnational Connections and a National Identity: Zanzibari Omanis in Muscat. In Monarchies and Nations: Globalisation and Identity in the Arab States of the Gulf, edited by P. Dresch and J. Piscatori, 96-113. London: Tauris.

Alber, E., and T. Häberlein. 2010. Ethnologische Genereationenforschung in Afrika. In Verwandtschaft heute: Positionen, Ergebnisse und Perspektiven, edited by E. Alber, B. Beer, J. Pauli, and M. Schnegg, 281-304. Berlin: Reimer.

Amit, V., S. Anderson, V. Caputo, J. Postill, D. Reed-Danahay, and G. Vargas-Cetina. 2015. Introduction: Thinking through Sociality; The Importance of Mid-level Concepts. In Thinking through Sociality, edited by V. Amit, 1-20. New York: Berghahn Books.

Baldassar, L., and L. Merla. 2014. Transnational Families, Migration and the Circulation of Care: Understanding Mobility and Absence in Family Life. London: Routledge.

Bell, D., and M. Jayne. 2006. Small Cities: Urban Experience beyond the Metropolis. Abingdon: Routledge.

Caldeira, T. P. R. 2000. City of Walls: Crime, Segregation, and Citizenship in São Paulo. Berkeley: University of California Press.

Caplan, P., and F. Topan, eds. 2004. Swahili Modernities: Culture, Politics, and Identity on the East Coast of Africa. Trenton: Africa World Press.

Celik, E. 2013. From Best Practices to Abolitionist Approach: Durban's Street Trading Policy in the Run-Up to the 2010 World Cup. In Living the City in Africa: Processes of 
This is an accepted manuscript of an article published by Taylor \& Francis in Anthropological Forum available at https://www.tandfonline.com/doi/full/10.1080/00664677.2019.1586644

Invention and Intervention, edited by B. Obrist, E. Macamo, and V. Arlt, 119-134. Zurich: LIT.

Charmaz, K. 2006. Constructing Grounded Theory: A Practical Guide through Qualitative Analysis. London: SAGE.

Cresswell, T. 2009. Place. In International Encyclopedia of Human Geography, edited by N. Thrift and R. Kitchen, 169-177. Oxford: Elsevier.

De Jong, W., C. Roth, F. Kinda, and S. Bhagyanath. 2005. Ageing in Insecurity: Case Studies on Social Security and Gender in India and Burkina Faso. Münster: LIT.

De Klerk, Josien. 2011. Being Old in Times of AIDS: Aging, Caring and Relating in Northwest Tanzania. Leiden: African Studies Centre.

Dossa, P., and C. Coe. 2017. Transnational Aging and Reconfiguration of Kin Work. In Global Perspectives of Aging, edited by S. Lamb. New Brunswick: Rutgers University Press.

Emirbayer, M., and A. Mische. 1998. What is Agency? American Journal of Sociology 103 (4): 962-1023. DOI:10.1086/231294.

Fair, L. 2004. Remaking Fashion in the Paris of the Indian Ocean: Dress, Performance, and the Cultural Construction of a Cosmopolitan Zanzibari Identity. In Fashioning Africa: Power and the Politics of Dress, edited by J. M. Allman. Bloomington: Indiana University Press.

Förster, T. 2013. On Urbanity: African Cities as Sites of Creativity and Emancipation. In Living the City in Africa: Processes of Invention and Intervention, edited by B. Obrist, E. Macamo, and V. Arlt, 235-252. Zurich: LIT.

Freudendal-Pedersen, M., and V. Cuzzocrea. 2015. Cities and Mobilities. City \& Society 27 (1): 4-8. DOI:10.1111/ciso.12050.

Gerold, J. 2013. On the Move: Elderly People Living the City of Dar es Salaam, Tanzania. In Living the City in Africa: Processes of Invention and Intervention, edited by B. Obrist, E. Macamo, and V. Arlt, 153-170. Zurich: LIT.

Glaser, B., and A. Strauss. 2010. Grounded Theory: Strategien qualitativer Forschung. 3rd ed. Bern: Huber.

Glick Schiller, N., L. Basch, and C. Blanc-Szanton. 1992. Towards a Definition of Transnationalism. Annals of the New York Academy of Sciences 645 (1): ix-xiv. DOI:10.1111/j.1749-6632.1992.tb33482.x.

Guggenheim, M., and O. Söderström, eds. 2010. Re-Shaping Cities: How Global Mobility Transforms Architecture and Urban Form. London: Routledge. 
This is an accepted manuscript of an article published by Taylor \& Francis in Anthropological Forum available at https://www.tandfonline.com/doi/full/10.1080/00664677.2019.1586644

Harvey, D. 2012. Rebel Cities: From the Right to the City to the Urban Revolution. London: Verso.

Herzig, P., and S. Thieme. 2007. How Geography Matters: Neglected Dimensions in Contemporary Migration Research. Asiatische Studien: Zeitschrift der Schweizerischen Asiengesellschaft 61 (4): 1077-1112. DOI:http://doi.org/10.5169/seals-147765.

Kaiser-Grolimund, A. 2018. Healthy Aging, Middle-classness, and Transnational Care between Tanzania and the United States. In Caring on the Move. Ethnographic Explorations of Aging and Migration Across Societies, edited by Azra Hromadžić and Monika Palmberger, 32-52. New York: Berghahn Books.

Keshodkar, A. 2013. Tourism and Social Change in Post-Socialist Zanzibar: Struggles for Identity, Movement, and Civilization. Lanham: Lexington Books.

Kleinman, A. 2012. Caregiving as Moral Experience. The Lancet 380 (9853): 1550-1551. DOI:http://dx.doi.org/10.1016/S0140-6736(12)61870-4.

Kleinman, A., and S. van der Geest. 2009. 'Care' in Health Care: Remaking the Moral World of Medicine. Medische Antropologie 21 (1): 159-168.Koechlin, L. 2015.

Conceptualising Corruption, Conflict and Cities in Africa: Towards a Typology of Urban Political Articulations. Basel Papers on Political Transformations 9 :3-28.

Kusenbach, M. 2003. Street Phenomenology: The Go-Along as Ethnographic Research Tool. Ethnography 4 (3): 455-485.

Lamb, S. 2009. Aging and the Indian Diaspora: Cosmopolitan Families in India and Abroad. Bloomington: Indiana University Press.

Lancione, M. 2016. The Assemblage of Life at the Margins. In Rethinking Life at the Margins: The Assemblage of Contexts, Subjects and Politics, edited by M. Lancione, 3-26. New York: Routledge.

Larsen, K. 2004. Change, Continuity and Contestation: The Politics of Modern Identities in Zanzibar. In Swahili Modernities: Culture, Politics, and Identity on the East Coast of Africa, edited by P. Caplan and F. Topan, 121-143. Trenton: Africa World Press.

Lefebvre, Henri. 1974 [1996]. The Production of Space. Reprint ed. Oxford: Basil Blackwell. Levitt, P., and N. Glick Schiller. 2004. Conceptualizing Simultaneity: A Transnational Social Field Perspective on Society. International Migration Review 38 (3): 1002-1039. Loimeier, R. 2007. Sit Local, Think Global: The Baraza in Zanzibar. Journal for Islamic Studies 27: 16-38. 
This is an accepted manuscript of an article published by Taylor \& Francis in Anthropological Forum available at https://www.tandfonline.com/doi/full/10.1080/00664677.2019.1586644

Loimeier, R., and R. Seesemann. 2006. Introduction: The Global Worlds of the Swahili; Interfaces of Islam, Identity and Space in 19th and 20th-Century East Africa. In The Global Worlds of the Swahili: Interfaces of Islam, Identity and Space in 19th and 20th-Century East Africa, edited by R. Loimeier and R. Seesemann, 1-14. Berlin: LIT.

Long, N. J., and H. L. Moore. 2012. Sociality: Resetting the Agenda. Cambridge Anthropology 30 (1): 40-142. DOI:http://dx.doi.org/10.3167/ca.2012.300105.

Makoni, S., and K. Stroeken. 2002. Towards Transdisciplinary Studies on Ageing in Africa. In Ageing in Africa: Sociolinguistic and Anthropological Approaches, edited by S. Makoni and K. Stroeken. Aldershot: Ashgate.

Mazrui, A. M. 2007. Swahili beyond the Boundaries: Literature, Language, and Identity. Athens: Ohio University Press.

Mazrui, A. M., and I. N. Shariff. 1994. The Swahili: Idiom and Identity of an African People. Trenton: Africa Research \& Publications.

McCann, E., and K. Ward. 2011. Mobile Urbanism: Cities and Policymaking in the Global Age. Minneapolis: University of Minnesota Press.

Middleton, J. 2004. African Merchants of the Indian Ocean: Swahili of the East African Coast. Long Grove: Waveland.

Mol, A. 2008. The Logic of Care: Health and the Problem of Patient Choice. London: Routledge.

Myers, G. A. 2011. African Cities: Alternative Visions of Urban Theory and Practice. London: Zed Books.

Nuttall, S., and A. Mbembe. 2004. Johannesburg: The Elusive Metropolis. Durham: Duke University Press.

Obrist, B. 2013. Introduction to Living the City in Africa. In Living the City in Africa: Processes of Invention and Intervention, edited by B. Obrist, E. Macamo, and V. Arlt, 9-22. Zurich: LIT.

Obrist, B. 2016. Place Matters: The Home as a Key Site of Old-Age-Care in Coastal Tanzania. In Ageing in Sub-Saharan Africa: Spaces and Practices of Care, edited by J. Hoffman and K. Pype. Bristol: Policy Press.

Raban, J. 1974. Soft City. New York: E. P. Dutton.

Robinson, J. 2006. Ordinary Cities: Between Modernity and Development. London: Routledge. 
This is an accepted manuscript of an article published by Taylor \& Francis in Anthropological Forum available at https://www.tandfonline.com/doi/full/10.1080/00664677.2019.1586644

Robinson, J. 2011. Cities in a World of Cities: The Comparative Gesture. International Journal of Urban and Regional Research 35 (1): 1-23.

Simone, A. M. 2004. For the City Yet to Come: Changing African Life in Four Cities. Durham: Duke University Press.

Skrbis, Z., G. Kendall, and I. Woodward. 2004. Locating Cosmopolitanism: Between Humanist Ideal and Grounded Social Category. Theory, Culture \& Society 21 (6): $115-122$.

Söderström, O., B. Dupuis, and P. Leu. 2013. Translocal Urbanism: How Ouagadougou Strategically Uses Decentralized Cooperation. In Living the City in Africa: Processes of Invention and Intervention, edited by B. Obrist, E. Macamo, and V. Arlt, 99-118. Zurich: LIT.

Staudacher, S. 2019. Cosmopolitan Aging in Zanzibar: Elderhood, Health and Transnational Care Spaces to Oman. PhD diss., University of Basel.

United Nations, Department of Economic and Social Affairs, Population Division. 2015. World Urbanization Prospects: The 2014 Revision. New York: United Nations.

United Republic of Tanzania, National Bureau of Statistics and Office of Chief Government Statistician. 2013. Population Distribution by Age and Sex.

Van der Geest, S. 2002. Respect and Reciprocity: Care of Elderly People in Rural Ghana. Journal of Cross-Cultural Gerontology 17 (1): 3-31.

DOI:https://doi.org/10.1023/A:1014843004627.

Van Eeuwijk, P. 2002. Ageing and Health in Urban Indonesia. Urban Health and Development Bulletin 5 (3/4): 25-31.

Van Eeuwijk, P. 2004. Altern und Gesundheit in Städten Indonesiens: Medizinethnologische Forschung zu 'Health Transition'. Tsantsa 9: 123-126.

Van Eeuwijk, P. 2006. Old-Age Vulnerability, Ill-Health and Care Support in Urban Areas of Indonesia. Ageing \& Society 26 (1): 61-80. DOI:https://doi.org/10.1017/S0144686X05004344.

Van Eeuwijk, P. 2014. The Elderly Providing Care for the Elderly in Tanzania and Indonesia: Making 'Elder to Elder' Care Visible. Sociologus 64 (1): 29-52.

Verne, J., and D. Müller-Mahn. 2013. 'We Are Part of Zanzibar' - Translocal Practices and Imaginative Geographies in Contemporary Oman-Zanzibar Relations. In Regionalizing Oman: Political, Economic and Social Dynamics, edited by S. Wippel. New York: Springer. 
This is an accepted manuscript of an article published by Taylor \& Francis in Anthropological Forum available at https://www.tandfonline.com/doi/full/10.1080/00664677.2019.1586644

Vierke, U., and N. Siegert. 2013. Urban Memories and Utopias: Contemporary Art in Luanda and Nairobi. In Living the City in Africa: Processes of Invention and Intervention, edited by B. Obrist, E. Macamo, and V. Arlt, 135-152. Zurich: LIT.

World Health Organization. 2007. Global Age-Friendly Cities: A Guide. Geneva: World Health Organization.

Zanzibar, Revolutionary Government of, President Office, Finance, Economy and Development Planning. 2012. Impact Assessment on Retirement Environment in Zanzibar.

\section{Notes}

1 Acknowledgements: I am grateful to all research participants and helpers in the fields in Zanzibar and Oman, as well as to everyone involved in my $\mathrm{PhD}$ research on which this article builds on. $\mathrm{My} \mathrm{PhD}$ study was part of the larger and comparative research project "Aging, Agency and Health in Urbanizing Tanzania" led by Prof. Dr. Brigit Obrist and PD Dr. Peter van Eeuwijk, both from the University of Basel. The project was funded by the Swiss National Science Foundation (no. 140425 and no. 152694) and conducted in collaboration with the State University of Zanzibar and the University of Dar es Salaam in Tanzania. The Tanzanian National Institute for Medical Research (NIMR/HQ/R.8a/Vol.IX/1376 and NIMR/HQ/R.8a/Vol.II/266) and the Tanzania Commission for Science and Technology (COSTECH no. 2012-386-NA-2012-125 and no. 2013-305-NA-2013-81) as well as the Zanzibar Research Committee approved the project. In Oman, Dr. Salem Said Al Touby, Dean of the Oman Nursing Institute of the Ministry of Health supervised the research in Muscat. I conducted the field research in Zanzibar and Oman together with the research assistants Saada Omar Wahab, Saleh Mohammed Saleh and Nujaida Mohammed Al Maskari. Finally, I wish to thank for the helpful comments of the editors of this special issue, as well as of the anonymous reviewers on a previous version of this paper. Thanks, also to Anthony Mahler for the language editing.

2 I translated all the quotations from the interviews from Swahili into English.

$3 \mathrm{Bi}$ is the abbreviation of bibi, which means both 'Ms.' and 'grandmother'.

4 For the analysis, I worked with the qualitative data analysis software MAXQDA and was inspired by Charmaz's (2006) interpretation of grounded theory, which Glaser and Strauss (2010) developed in the 1960s. Using both theoretical and emic categories, I coded over two hundred audio-recorded interviews. I discussed my preliminary findings with each older informant and with Tanzanian academics as well as state and NGO representatives during dissemination workshops at the State University of Zanzibar and the University of Dar es Salaam.

5 This analysis was developed together with Barbara Heer, Andrea Grolimund, and Carole Ammann in preparing two panels at the 2016 EASA conference in Milan, Italy. 
6 A refreshing counterexample to this trend is Sion Eryl Jones's blog post for the NGO HelpAge International with the topic ' 10 ways Habitat III can protect and promote our rights in older age'.

7 I mean place here in the sense of Cresswell $(2009,169)$ as 'a meaningful site that combines location, locale, and sense of place'. Cresswell defines the element location as an 'absolute point in space', which has a certain distance from other locations and defines where a place is. Locale includes the material setting for social relations as the "buildings, streets, parks, and other visible and tangible aspects of a place' (Cresswell 2009, 169). With sense of place, he understands the individual or shared 'meanings associated with a place: the feelings and emotions a place evokes' (Cresswell 2009, 169).

8 I understand space, in contrast, as how people interact with and relate to people, commodities, and ideas between diverse places. Space in this sense is a social product based on values and meanings that affect spatial practices and perceptions (Lefebvre 1974 [1996]).

9 It is common to speak of care giving and care receiving, but considering older people's agency, 'care taking' would better describe their active involvement in this process.

10 Aspects of transnational urbanism have been discussed by, among others, Guggenheim and Söderström (2010); Söderström, Dupuis, and Leu (2013); McCann and Ward (2011), who investigate municipal administrations' recent strategy of decentralised cooperation and the 'translocal' engagement of experts. Other studies have looked at marginalised groups engaged in transnational urban art and sports projects (Celik 2013; Vierke and Siegert 2013).

11 Older urban residents are often also care givers (Van Eeuwijk 2014) and not only care receivers. 